Report No. BMI-1139

Metallurgy and Ceramics

(TID-4500, 12th Ed.)

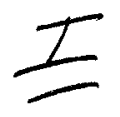

Contract No. W-7405-eng-92

\title{
DUCTILITY OF TUNGSTEN-ARC WELDS \\ IN MOLYBDENUM
}

\author{
by
}

Norman E. Weare

Robert E. Monroe

David C. Martin

\author{
October 10, 1956 \\ BATTELLE MEMORIAL INSTITUTE \\ $505 \mathrm{King}$ Avenue \\ Columbus 1, Ohio
}




\section{DISCLAIMER}

This report was prepared as an account of work sponsored by an agency of the United States Government. Neither the United States Government nor any agency Thereof, nor any of their employees, makes any warranty, express or implied, or assumes any legal liability or responsibility for the accuracy, completeness, or usefulness of any information, apparatus, product, or process disclosed, or represents that its use would not infringe privately owned rights. Reference herein to any specific commercial product, process, or service by trade name, trademark, manufacturer, or otherwise does not necessarily constitute or imply its endorsement, recommendation, or favoring by the United States Government or any agency thereof. The views and opinions of authors expressed herein do not necessarily state or reflect those of the United States Government or any agency thereof. 


\section{DISCLAIMER}

Portions of this document may be illegible in electronic image products. Images are produced from the best available original document. 


\section{II}

TABLE OF CONTENTS

$\underline{\text { Page }}$

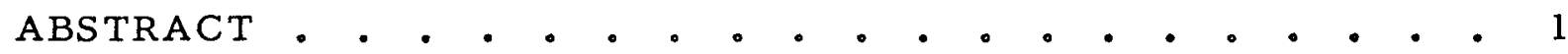

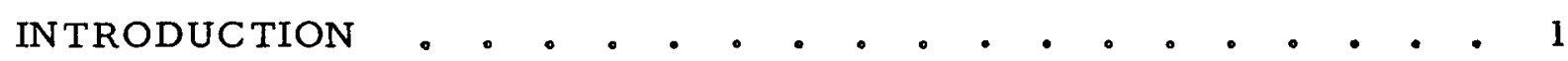

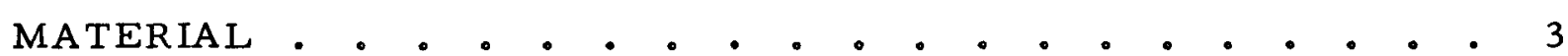

EXPERIMENTAL PROCEDURES • • • • • • • • • • • •

Equipment • • . • . • . - . . . . . . 6

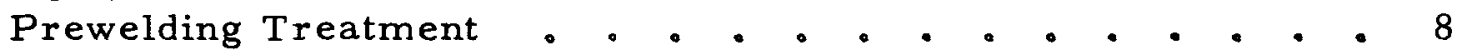

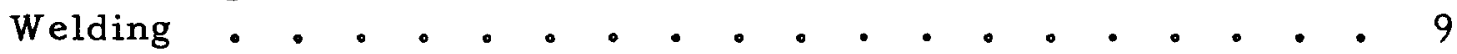

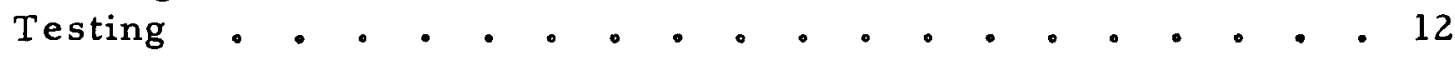

EXPERIMENTAL RESULTS

Studies Made in the Dry Box • . . . . . . . . . 13

Studies Made in Air • . • • . . . . . • . . . 15

Weld Porosity . . . . . . . . . . . . . . . 19

Tungsten Contamination . . . . . . . . . . . . 20

CONSISTENCY RUN • • • • • • • • • • • • • • • • 22

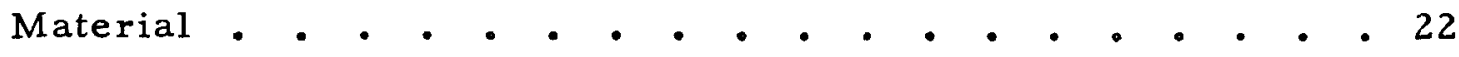

Procedures . . . . . . . . . . . . . . . . 22

Results • • • • • • • • • • . • • • • • • • 25

SUMMARY • • • • • • • • • • • • • • • • • • • 28

REFERENCES • • • . • • • • • • • • • • • • • 29 


\title{
DUCTILITY OF TUNGSTEN-ARC WELDS IN MOLYBDENUM
}

\author{
Norman E. Weare, Robert E. Monroe, \\ and David C. Martin
}

$$
E M-1139
$$

The objectives of this study were (1) to study some of the variables encountered in welding molybdenum, (2) to study the possibility of welding molybdenum outside of a dry box, and (3) to determine if welds of consistent ductility could be made in different lots of arccast carbon-deoxidized molybdenum. Good bend ductility at 25 and 75 $C$ was found for welds made using the best procedures established for dry-box and conventional welding.

Welds were made in the dry box to study the effects of cleaning methods, initial sheet microstructure, and two levels of atmosphere purity. Only atmosphere purity had a significant effect on weld ductility. Five methods of shielding welds made in air were studied. The effects of type of inert gas used, gas flow, and nozzle size were determined with standard inert-gas-shielding cups. A standard shielding cup and a leading-trailing shield unit have produced the best welds made in air to date. Other promising shielding methods are still being studied. The extent of tungsten contamination of molybdenum welds during tungstenarc welding also was studied. About $3 \mathrm{w} /$ o tungsten in a molybdenum weld lowered weldment ductility. Weld porosity was associated with oxides or gas trapped along sheet edges.

Welds were made in six heats of arc-cast molybdenum with about the same carbon content, both in air and in the dry box, for a consistency run. A significant difference in bend ductility was found among welds made in the different heats.

\section{INTRODUCTION}

Good bend ductility in tungsten-arc welds in arc-cast carbondeoxidized molybdenum was obtained during studies of conventional and drybox inert-gas-shielding methods. This study determined the effects of cleaning procedures, sheet structure, atmosphere purity, and tungsten contamination. Preliminary studies of shielding methods for conventional welding and a ductility consistency run on weldments from six heats of commercial molybdenum were also completed. Attempts were made to eliminate weld porosity sometimes found in butt joints.

Molybdenum has many properties which would make it a useful structural material for high-temperature uses. The major drawback to the use of molybdenum in liquid-metal or salt systems is low weld-bend ductility

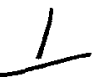


between room temperature and about $400 \mathrm{~F}$. Research programs during the past several years have been conducted to overcome the weld-ductility problem. Important gains were made with the discovery that fairly ductile welds could be made in recent commercial molybdenum in high-purity drybox atmospheres. (1) Most significantly, these welds were made by the widely used and versatile tungsten-arc welding process.

Since earlier work(1) was devoted to comparing a large number of molybdenum alloys, standard procedures were followed in producing test weldments. These procedures were believed to be satisfactory, but alternate methods were available in many cases. Tests to establish optimum procedures were made by studying cleaning methods, preweld sheet structure, and atmosphere purity. Weldments made in a dry box were bend tested using single-point loading at a high strain rate to determine the effects of these variations.

While many welding jobs could be done in a dry box, final assembly of components and welding of large pieces would have to be done in air. A preliminary study was made of some methods of shielding molybdenum for welding outside the dry box. Five shielding methods were studied:

(1) A standard ceramic inert-gas-shielding cup

(2) A leading and trailing shield unit

(3) A leading shield

(4) A plastic bag to shroud the weld area from the air

(5) A dragging shield.

In all cases, a helium-gas backup was used to protect the back of the weld. A study was also made of the effects of gas flow, nozzle size, and type of gas used on weld ductility.

Small amounts of tungsten were seen dropping from the tip of the electrode while welding in air. Attempts were made to determine the extent of tungsten contamination in tungsten-arc welds in molybdenum and its effect on weld ductility.

Good bend ductility was obtained for all welds made in the dry box. Of the cleaning methods studied, etching in a chromic acid solution was chosen as the best and most practical method to clean molybdenum for welding. Welds made in a high-purity atmosphere were slightly more ductile than welds made in a low-purity atmosphere. Recrystallization of sheet prior to welding had no effect on weld ductility. Weldments made at the

${ }^{(1)}$ References given at end of report. 
best conditions had an average bend angle of $64 \mathrm{deg}$ before fracture when bent at $1 \mathrm{ipm}$ at room temperature.

Of the shielding methods tried in air, the ceramic cup and the leading-trailing shield unit produced welds with good ductility, but not equal to dry-box welds. From the studies made using the ceramic cup, it was found that a helium flow of $40 \mathrm{cfh}$ through a 5/8-in.-diameter nozzle produced the most ductile welds. Welds made in the plastic bag were very porous and showed no improvement in ductility. Results of tests made using a leading shield and a dragging shield were inconclusive and future work will be done using these shields. Attempts to determine the extent of tungsten contamination during normal welding were unsuccessful. However, bend tests made on a molybdenum weld with tungsten deliberately added showed low room-temperature ductility.

Using the best conditions found for welds made in air and in the dry box, a consistency run was made on six different lots of molybdenum. The results of this consistency run showed a significant difference in weldment bend ductility among different heats of arc-cast molybdenum of about the same carbon content. There was a much more significant difference among welds made in air than among welds made in the dry box.

This report is divided into sections describing the materials, the experimental procedures, the experimental results, and the consistency run. Under the section on experimental results discussions of welds made in the dry box, welds made in air, porosity, and tungsten contamination are found. The section on the consistency run describes materials, procedures, and results.

\section{MATERIAL}

A single sheet (C20) of 1/16-in.-thick carbon-deoxidized arc-cast molybdenum containing $0.017 \mathrm{w} / \mathrm{o}$ carbon was used for most of the welding studies. Results of transverse bend tests (Table 1) on Sheet C20 showed a lower ductility than for sheet tested in previous studies. For comparison, data are included in Table 1 for bend tests at room temperature on the commercial material (Sheet C12) used in previous work. Since the roomtemperature ductility was low for the sheet, tests were made at a temperature above $25 \mathrm{C}$ to see if consistent 90-deg* bending without fracture could be obtained. At $75 \mathrm{C}$ (the first temperature tried) consistent 90 -deg bending was obtained without fracture.

- Limit of test equipment. 
TABLE 1. DUCTILITY OF SHEET USED FOR WELDING STUDIES

Sheet Stress Relieved $1 \mathrm{Hr}$ at $1800 \mathrm{~F}$ in Hydrogen

\begin{tabular}{|c|c|c|c|}
\hline \multirow[b]{2}{*}{ Sheet } & \multirow{2}{*}{$\begin{array}{c}\text { Carbon } \\
\text { Content, } \\
\text { w/o }\end{array}$} & \multicolumn{2}{|c|}{$\begin{array}{c}\text { Permanent Bend Angle(a) at Fracture, deg, in Tests at } \\
\text { Indicated Temperature }\end{array}$} \\
\hline & & $25 \mathrm{C}$ & $75 \mathrm{C}$ \\
\hline $\mathrm{C} 12$ & 0.046 & $\begin{array}{c}90 \mathrm{NF}^{(\mathrm{b})}, 90 \mathrm{NF}, 90 \mathrm{NF} \\
90\end{array}$ & Not tested \\
\hline $\mathrm{C} 20$ & 0.017 & $\begin{array}{c}8,40,70,90 \mathrm{NF}, 90 \mathrm{NF} \\
60\end{array}$ & $\begin{array}{c}90 \mathrm{NF}, 90 \mathrm{NF}, 90 \mathrm{NF}, 90 \mathrm{NF}, 90 \mathrm{NF} \\
90\end{array}$ \\
\hline $\mathrm{C} 21$ & 0.020 & $\begin{array}{c}90 \mathrm{NF}, 90 \mathrm{NF}, 90 \mathrm{NF}, \\
90 \mathrm{NF}, 90 \mathrm{NF} \\
90\end{array}$ & Not tested \\
\hline
\end{tabular}

(a) Average value for each set of samples is underlined.

(b) NF = no fracture.

Metallographic examination of this sheet showed very coarse grains elongated in the direction of rolling. The surface of the sheet was cold worked more severely because of the chilling effect of the rolls. There was evidence of laminations between the fibered surface and the coarsegrained interior of the sheet. Massive carbides were also visible in the sheet. Figures 1 and 2 show the microstructure of the sheet. Examination of this sheet when it was rolled to about 0.080 in. thick showed a completely recrystallized grain structure. Not enough cold work was put into the sheet between 0.080 and 0.062 in. to produce a ductile, fibered structure. Sheets $\mathrm{C} 12$ (used in previous work) and $\mathrm{C} 2 \mathrm{l}$ were fibered and showed much better bend ductility. Sheet C21 was chosen to study the effect of recrystallization of the sheet on weld ductility.

\section{EXPERIMENTAL PROCEDURES}

In previous studies of titanium-neutralized and carbon-deoxidized arc-cast molybdenum, special equipment and procedures were developed to minimize weld contamination. This study did not include work on the effects of treatment and welding variables on the weldment ductility. These procedures were modified in this program to study the effects of sheetcleaning procedures, sheet microstructure, and atmosphere purity on the ductility of weldments made in a dry box. Since welding in a dry box would not always be practical, preliminary work was also done to develop procedures for the inert-gas-shielded tungsten-arc welding of molybdenum in air. Variables studied were shielding devices, shielding gas, and gas flows. Attempts to determine the cause of porosity and the extent and effect of 


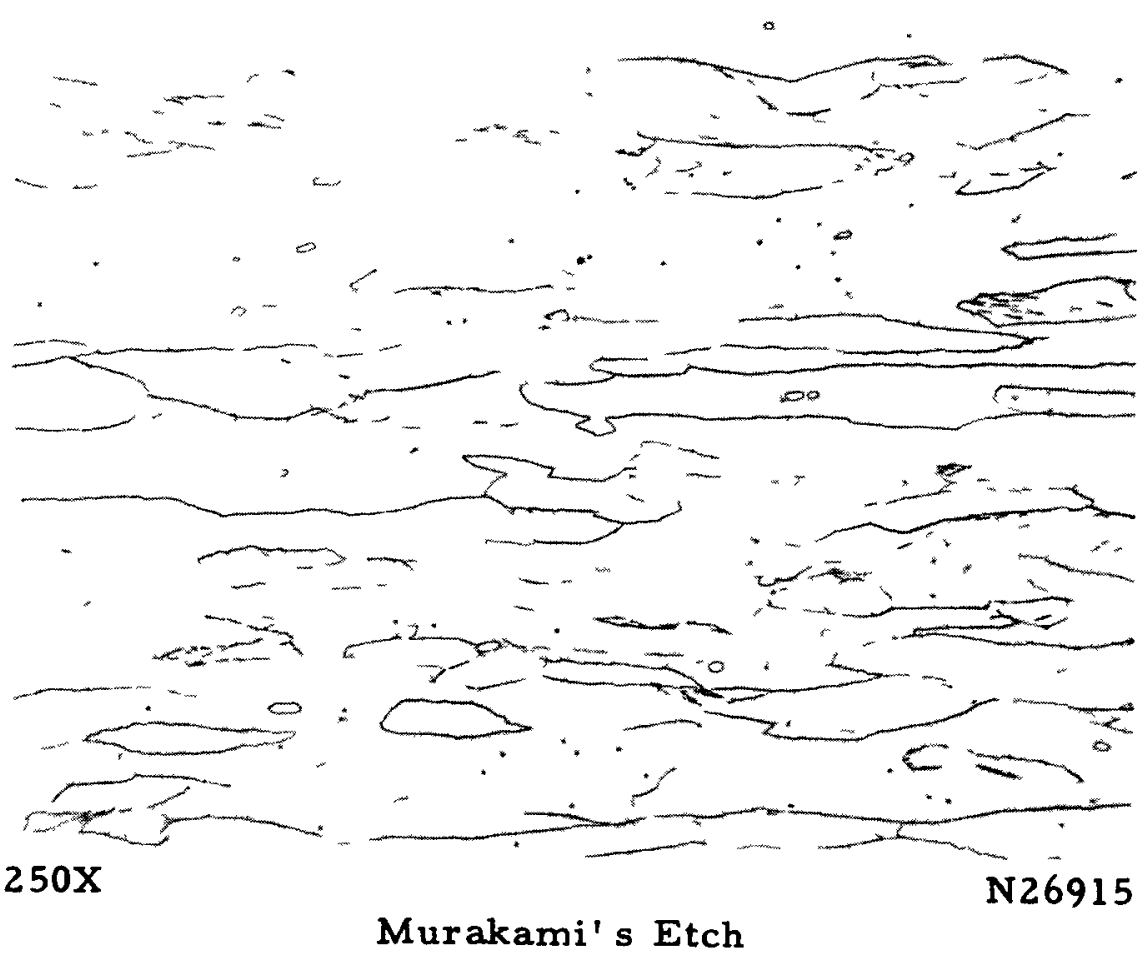

FIGURE 1. LONGITUDINAL SECTION OF SHEET C20

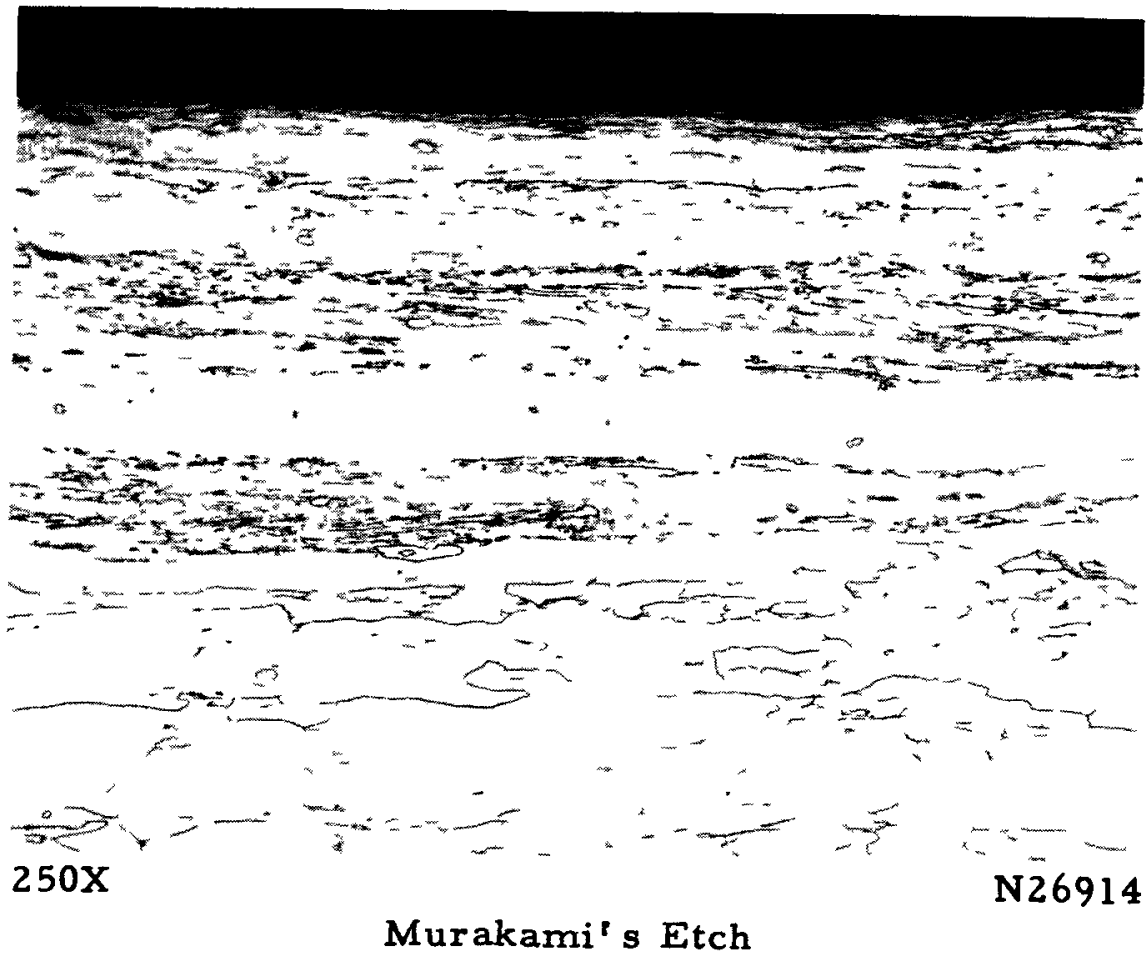

FIGURE 2. TRANSVERSE SECTION OF SHEET C20 SHOWING THE FIBERED SURFACE 
tungsten contamination of inert-gas-shielded tungsten-arc welds were made also. The section following describes the equipment used in welding and the procedures used before, during, and after welding.

\section{$\underline{\text { Equipment }}$}

The welding dry box and auxiliary equipment used for this study were described previously. (1) This dry box is purged to a vacuum of $0.1 \mu$ of mercury. By rapidly admitting gas from a high-pressure cylinder and gettering the atmosphere by welding on titanium or zirconium, a highpurity welding atmosphere can be obtained. A constant-voltage welding head, a 400-amp d-c rectifier, and a moving carriage were used for welds made in the dry box and in air.

Shielding devices used for the study of weldments made in air were:

(1) A standard ceramic inert-gas-shielded welding cup

(2) A leading and trailing shield unit

(3) A leading shield

(4) A plastic bag to shroud the welding area

(5) A dragging shield.

The leading-trailing shield unit, the leading shield, and the dragging shield were all used in conjunction with an inert-gas-shielding cup. In all cases, a helium backup was used.

The ceramic cups (Figure $3 a$ ) used had 3/8-, 1/2-, and 5/8-in.diameter gas orifices. The gas surrounded the tungsten electrode and the arc, and protected the molten weld pool. The trailing shield unit (Figure $3 \mathrm{~b}$ ) consisted of a leading shield, a ceramic cup, and a trailing shield. This shield unit fit on the ceramic cup and gas protected the area ahead of the arc, the molten weld pool, and the completed weld from oxidation. A gas baffle, consisting of a porous stainless steel sheet, was brazed into the shield to give a more even gas flow. A leading shield (Figure 3c) was designed to protect the unwelded portion of the joint ahead of the arc from oxidation. This shield was designed for use with the 5/8-in. ceramic inertgas-shielding cup. A porous stainless steel gas baffle was brazed into the shield to produce a uniform gas flow.

To shroud the entire weld area from the air, a polyethylene bag clamped between the electrode holder and a special jig was made to determine if weld ductility could be improved using this method. No cup was used in connection with the plastic bag. Gas was admitted to the bag through 

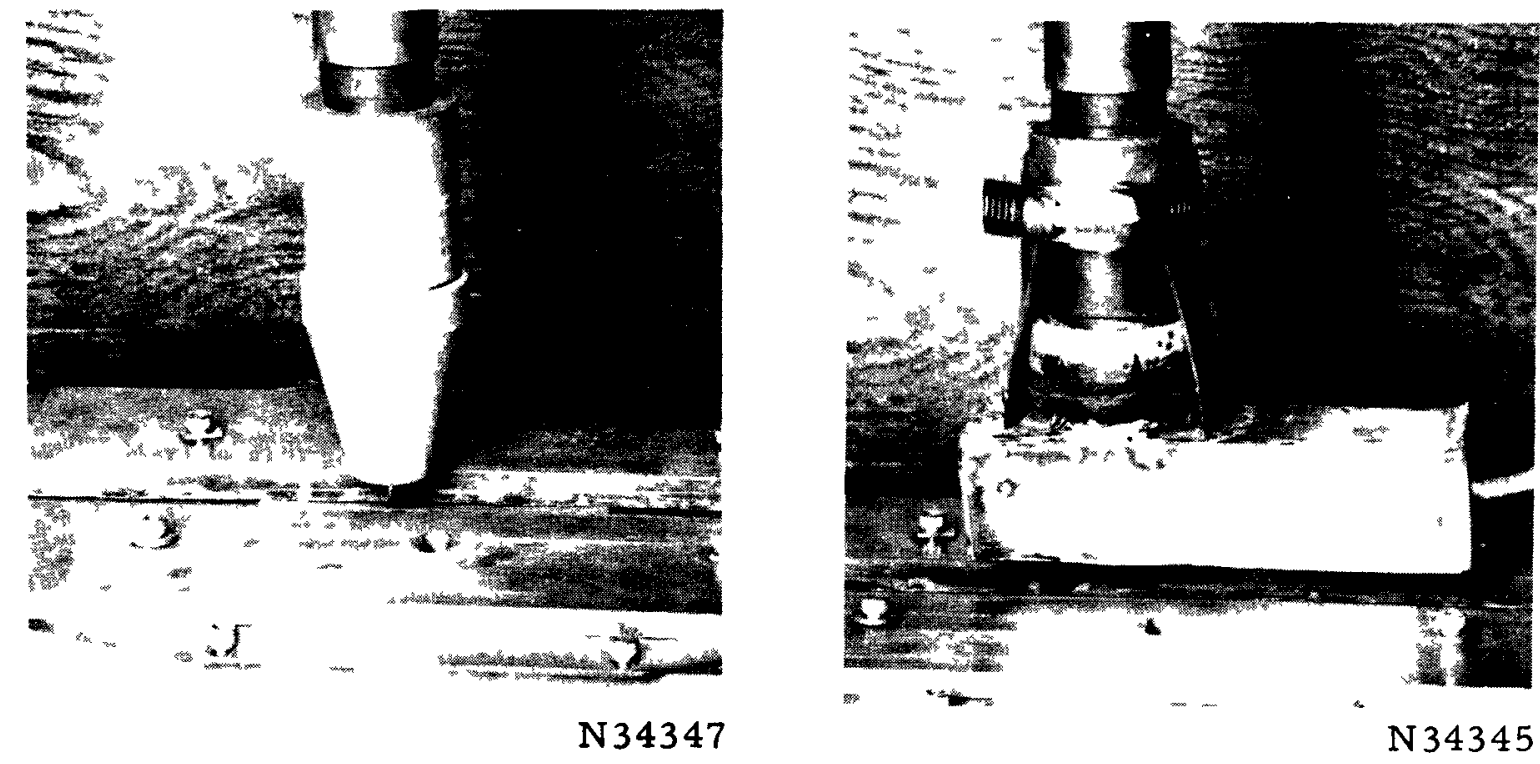

a. Ceramic Inert-Gas-Shielding Cup

b. Leading-Trailing Shield Unit
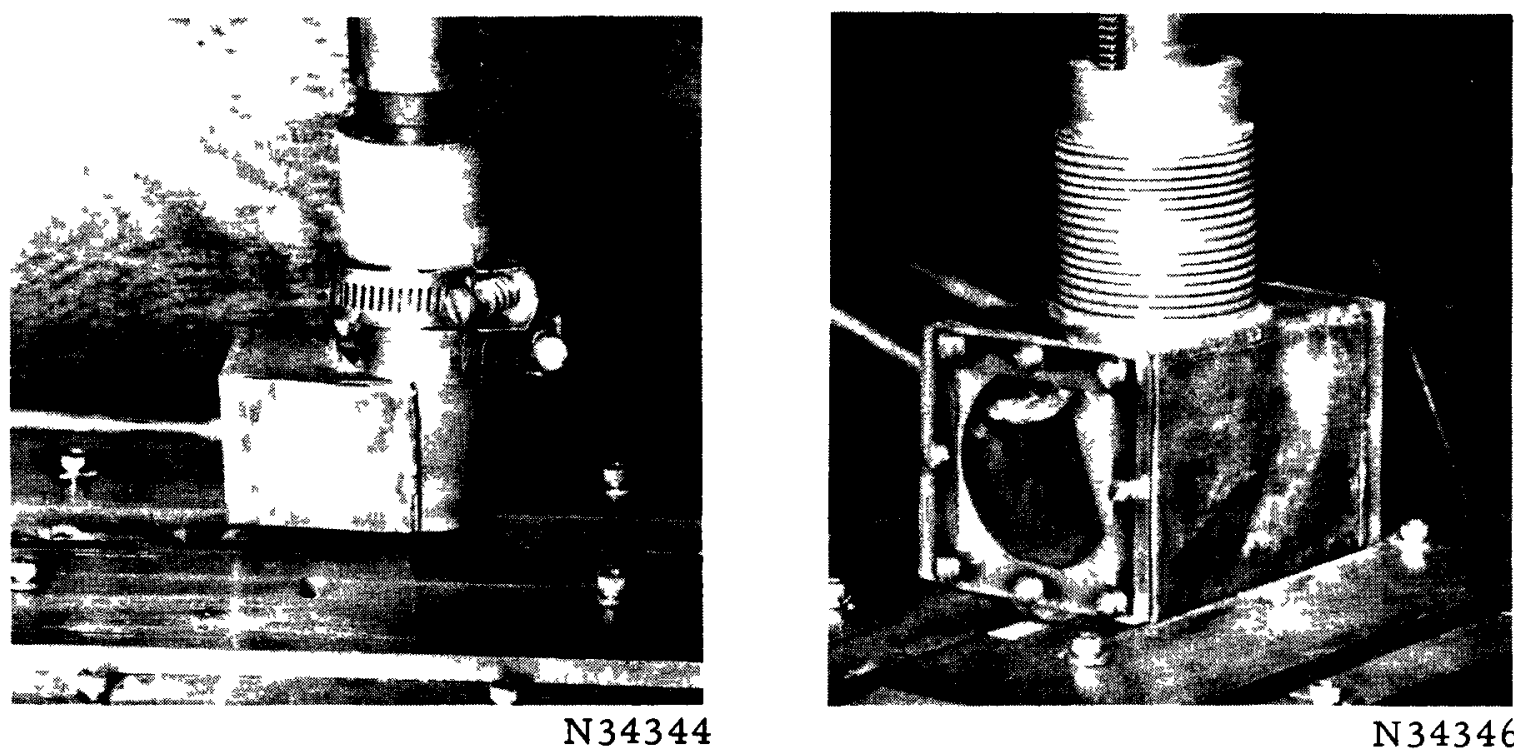

c. Leading Shield

d. Dragging Shield

FIGURE 3. SHIELDS USED TO PROTECT MOLYBDENUM WELDMENTS MADE OUTSIDE THE DRY BOX

Carriage moved from left to right under the arc. 
a backup and through the welding head, and a positive pressure was maintained throughout purging and welding operations by adjusting gas-outlet valves in the bottom of the jig.

A dragging shield (Figure 3d) was designed to fit directly on the molybdenum sheet being welded and act somewhat as a welding chamber to shield the weld from the air. This shield was made to fit the contour of the welding jig, leaving a small gap to allow gas to escape during welding. Plexiglas windows were placed at each end of the shield to facilitate alignment and to allow observation of the weld being made.

In all cases, a gas backup was used to provide protection for the back of the weld. This backup consisted of two pieces of 3/16 by 1/2-in. copper bar with a 1/8-in. spacer for the bottom. A strip of porous stainless steel was forced into the 1/8-in. gap for the entire length. Helium was admitted to the backup at each end.

\section{Prewelding Treatment}

The cleaning of joint surfaces before welding is particularly important in producing ductile fusion weldments in molybdenum. Slight oxide films and, possibly, high impurity levels at the sheet surface can cause embrittlement of molybdenum weldments. A study was made of the four following cleaning methods:

(1) The surface was cleaned with a fine emery cloth and degreased in acetone.

(2) The sheet was etched for $30 \mathrm{sec}$ in a chromic acid etch (95 volume per cent $\mathrm{H}_{2} \mathrm{SO}_{4}, 4.5$ volume per cent $\mathrm{HNO}_{3}$, 0.5 volume per cent $\mathrm{HF}$, and $18.8 \mathrm{~g}$ per liter $\left.\mathrm{Cr}_{2} \mathrm{O}\right)$.

(3) The sheet was etched electrolytically $30 \mathrm{sec}$ in Coon's electrolyte $(150 \mathrm{ml}$ methyl alcohol absolute, $50 \mathrm{ml} \mathrm{HCl}$, and $\left.20 \mathrm{ml} \mathrm{H}_{2} \mathrm{SO}_{4}\right)$.

(4) The sheet was etched electrolytically in a solution of 50 volume per cent $\mathrm{H}_{2} \mathrm{O}$ and 50 volume per cent $\mathrm{HCl}$ for $30 \mathrm{sec}$.

All cleaning methods were followed by a hot-water rinse, then an acetone rinse. The chromic acid etch was used for all welds made in air and all remaining welds made in the chamber to study variables other than cleaning procedures. Heavy oxide on Sheet $\mathrm{C} 20$ was removed in a molten martempering salt bath. All other sheet was received with the heavy oxide removed. 
Other sheet was prepared to study the effects of prior sheet microstructure on the ductility of weldments. Since Sheet C20, used for most of the studies, was coarse grained, specimens were cut from a fibered sheet (Sheet C21) for welding studies. One specimen was welded in the as-rolled condition and the other was recrystallized at $2000 \mathrm{~F}$ for $2 \mathrm{hr}$ in flowing tank hydrogen prior to welding.

\section{Welding}

The normal welding procedures used in the dry box were the following:

(1) Specimens were loaded after cleaning.

(2) The dry box was evacuated to $0.1 \mu$ of mercury.

(3) Gas was admitted directly from a high-pressure cylinder.

(4) A getter arc was run on titanium for several minutes before welding each molybdenum sample.

To obtain a low-purity atmosphere, the chamber was evacuated to a vacuum of $100 \mu$ of mercury, and gas was admitted. The atmosphere was not gettered. Welding conditions for welds made in the dry box are given in Table 2. Most welds made in the dry box were bead-on-plate welds.

Square-butt welds were made in air using helium or argon as a shielding gas. Before welding the ceramic cups and the special shielding, units were dried to drive off any moisture they had picked up. Helium was allowed to flow through the equipment to dry it out and welds were made on scrap to assist in drying the electrode collet and gas backup. In using the plastic-bag shield, helium was allowed to flow through the backup and through the welding head for about 5 min to purge the bag of air. Helium remained flowing while the weld was being made. Two gas outlets in the bottom of the jig were adjusted to maintain a positive pressure in the bag. No shielding cup was used around the electrode. The dragging shield was purged for 2 min before welding.

Welding specimens were held on a copper jig by two hold-down plates and moved under the arc on a traveling carriage. Starting and finishing tabs were used for all butt welds. All welds, except the one made using argon, were made with the constant-voltage welding head. Since the head could not be controlled properly in argon with straight-polarity direct current, the welding head was used as a fixed torch and the arc was started by a high-frequency spark. A helium-gas backup was used for all welds made in air. No filler metal was used for either the welds made in air or those made in the dry box. Table 3 gives the data for welds made in air. Completed welds were stress relieved $1 \mathrm{hr}$ at $1800 \mathrm{~F}$ in flowing hydrogen. 
TABLE 2. WELDING CONDITIONS FOR TUNGSTEN-ARC WELDS MADE IN THE DRY BOX

Grade A Helium Atmosphere, Straight-Polarity D-C Voltage, Sensitivity

Control Normal, 1/8-In. Thoriated-Tungsten Electrode

\begin{tabular}{|c|c|c|c|c|c|c|c|}
\hline Weld & $\begin{array}{l}\text { Cleaning } \\
\text { Method }\end{array}$ & $\begin{array}{c}\text { Ultimate } \\
\text { Vacuum, } \\
\mu \text { of mercury }\end{array}$ & $\begin{array}{c}\text { Prior } \\
\text { Heat } \\
\text { Treatment }\end{array}$ & $\begin{array}{l}\text { Welding } \\
\text { Current, } \\
\text { amp }\end{array}$ & $\begin{array}{l}\text { Arc } \\
\text { Voltage, } \\
\text { v }\end{array}$ & $\begin{array}{l}\text { Weld } \\
\text { Speed, } \\
\text { ipm }\end{array}$ & Remarks \\
\hline $\mathrm{C} 20-1$ & Emery paper & 0.1 & None & 222 & 20 & 12 & 100 per cent penetration \\
\hline $\mathrm{C} 20-2$ & $\begin{array}{l}\text { Chromic acid } \\
\text { etch }\end{array}$ & 0.1 & None & 224 & 20 & 12 & 100 per cent penetration \\
\hline $\mathrm{C} 20-3$ & $\begin{array}{l}\text { Coon's electro- } \\
\text { lytic etch }\end{array}$ & 0.1 & None & 224 & 20 & 12 & 100 per cent penetration \\
\hline $\mathrm{C} 20-4$ & $\begin{array}{c}\mathrm{H}_{2} \mathrm{O}-\mathrm{HCl} \text { elec- } \\
\text { trolytic etch }\end{array}$ & 0.1 & None & 224 & 20 & 12 & 100 per cent penetration \\
\hline $\mathrm{C} 20-5$ & $\begin{array}{l}\text { Chromic acid } \\
\text { etch }\end{array}$ & 100.0 & None & 212 & 24 & 12 & $\begin{array}{l}100 \text { per cent penetration, } \\
\text { but not as much as } \\
\text { above }\end{array}$ \\
\hline C $21-1$ & $\begin{array}{l}\text { Chromic acid } \\
\text { etch }\end{array}$ & 0.2 & None & $220(a)$ & $20(a)$ & 12 & 100 per cent penetration \\
\hline C2 $1-2$ & $\begin{array}{l}\text { Chromic acid } \\
\text { etch }\end{array}$ & 0.2 & Recrystallized & $220^{(a)}$ & $20(a)$ & 12 & $\begin{array}{l}100 \text { per cent penetration, } \\
\text { electrode stuck at } \\
\text { beginning of weld }\end{array}$ \\
\hline
\end{tabular}

(a) Meters were not used, value estimated from previous welds. 
TABLE 3. WELDING CONDITION FOR INERT-GAS-SHIELDED MOLYBDENUM WELDS MADE IN AIR

Straight-Polarity D-C Voltage, 1/8-In. Thoriated-Tungsten Electrode, 12-IPM Weld Speed

\begin{tabular}{|c|c|c|c|c|c|c|c|c|}
\hline \multirow[b]{2}{*}{ Weld } & \multirow[b]{2}{*}{$\begin{array}{l}\text { Shield } \\
\text { Used }\end{array}$} & \multicolumn{3}{|c|}{ Gas Flow (a) cfh } & \multirow{2}{*}{$\begin{array}{l}\text { Electrode } \\
\text { Protru- } \\
\text { sion(b), in. }\end{array}$} & \multirow{2}{*}{$\begin{array}{l}\text { Welding } \\
\text { Current } \\
\text { amp }\end{array}$} & \multirow{2}{*}{$\begin{array}{c}\text { Arc } \\
\text { Voltage, } \\
v\end{array}$} & \multirow[b]{2}{*}{ Remarks } \\
\hline & & Cup & Backup & $\begin{array}{l}\text { Trailing } \\
\text { Shield }\end{array}$ & & & & \\
\hline $\mathrm{C} 20-\mathrm{A}$ & 3/8-in. cup & 40 & 30 & $-\infty$ & $1 / 8$ & 222 & 20 & $\begin{array}{l}\text { Face of weld oxidized, longitudinal and transverse } \\
\text { cracks, back of weld bright }\end{array}$ \\
\hline $\mathrm{C} 20-\mathrm{B}$ & 5/8-in. cup & 30 & 30 & -- & $5 / 32$ & 208 & 16 & $\begin{array}{l}\text { Face of weld oxidized, some porosity, back of } \\
\text { weld bright }\end{array}$ \\
\hline $\mathrm{C} 20-\mathrm{C}$ & 5/8-in. cup & 40 & 30 & - & $1 / 8$ & 212 & 15 & $\begin{array}{l}\text { Face of weld oxidized, slight porosity, back of } \\
\text { weld bright }\end{array}$ \\
\hline $\mathrm{C} 20-\mathrm{D}$ & 5/8-in. cup & 40 & 30 & -- & $1 / 8$ & 214 & 15 & $\begin{array}{l}\text { Face of weld oxidized, slight porosity, back of } \\
\text { weld bright }\end{array}$ \\
\hline $\mathrm{C} 20-\mathrm{E}$ & 5/8-in. cup & 80 & 30 & -- & $1 / 8$ & 224 & 22 & $\begin{array}{l}\text { Slightly oxidized surface, slight porosity, back } \\
\text { of weld bright }\end{array}$ \\
\hline $\mathrm{C} 20-\mathrm{F}$ & 5/8-in. cup & 15 (argon) & 30(helium) & -- & $1 / 8$ & 268 & 12.5 & $\begin{array}{l}\text { Face of weld oxidized, poor weld shape, large } \\
\text { amount of porosity, back of weld bright }\end{array}$ \\
\hline$C 20-G$ & $\begin{array}{l}\text { Trailing } \\
\text { shield }\end{array}$ & 40 & 30 & 30 & $1 / 8$ & 220 & 15 & $\begin{array}{l}\text { Face of weld bright, slight porosity, back of } \\
\text { weld bright }\end{array}$ \\
\hline $\mathrm{C} 20-\mathrm{H}$ & Plastic bag & 40 (c) & 30 & -- & $m$ & 206 & 17 & $\begin{array}{l}\text { Face of weld bright, gross porosity, cracks, } \\
\text { hole burned in bag at start of weld, back of } \\
\text { weld bright }\end{array}$ \\
\hline$C-20-1$ & Plastic bag & $40(c)$ & 15 & -- & -- & 210 & 17 & $\begin{array}{l}\text { Face of weld bright, gross porosity, back of } \\
\text { weld bright }\end{array}$ \\
\hline $\mathrm{C}^{20-\mathrm{J}^{(\mathrm{d})}}$ & 1/2-1n cup & 40 & 20 & - & $1 / 4$ & 210 & 17 & $\begin{array}{l}\text { Face of weld oxidized, large amount of porosity, } \\
\text { tungsten melted into weld, back of weld bright }\end{array}$ \\
\hline
\end{tabular}

(a) Grade A helium used except where noted.

(b) Electrode protrusion is the distance the electrode protrudes below the shielding device.

(c) No shielding cup used, gas flows around electrode.

(d) This weld was made using the circular jig made for the plastic bag. Greater electrode protrusion was required because of steep bevel on hold-down plates. 
Testing

Coarse-grained molybdenum structures exhibit a transition from a ductile to a brittle behavior around room temperature. In previous studies, tests over a temperature range have been used to determine transition temperatures for comparing materials. However, since in practice ductility below room temperature is at present unimportant, tests during this work were made at 25 and $75 \mathrm{C}$ only. By testing a number of small samples cut from each weld at each temperature, an average measure of ductility was obtained.

Bend tests were made transverse to the direction of rolling and welding. Under this type of loading, molybdenum has lower ductility than would be found in tension or longitudinal bending. Specimens were bent until fracture occurred or to a maximum angle of $90 \mathrm{deg}$. * The permanent bend angle after fracture was measured to indicate the degree of plastic deformation. The conditions used in bend testing are listed below:

Type of test

Simple single-point-loaded bend test

Test temperature

Deflection rate

Strain rate

Specimen dimensions
25 and $75 \mathrm{C}$

1 ipm

0.016 in. $/($ in. $)($ sec $)$ at start of bend

$1 / 16$ by $1 / 8$ by $3 / 4-$ in. minimum length

Tests at $25 \mathrm{C}$ were used to study the room-temperature ductility of the weldments. The sheet used for most of the work was not completely ductile at room temperature. In order to test weldments at a temperature above the sheet's brittle-ductile transition range, tests were made also at $75 \mathrm{C}$, which supplemented the data obtained at $25 \mathrm{C}$.

Since previous studies had shown an improvement in bend-test ductility for weld specimens with the tension face ground and rough polished, all specimens were tested with the weld surface ground. The first few welds tested did not have the surfaces ground completely flat, but depressions were left at the weld-fusion lines. Bend specimens from these welds had a tendency to fracture through this reduced section at low permanent bend angles. It was found that better ductility was obtained when the welds were ground flush on the surface. This also eliminated many of the fusion-line fractures. Surface grinding was done with a 150-mesh belt and polishing with a fine emery wheel or a 400-mesh belt to give a smooth surface for testing.

- Limit of test equipment. 
Room-temperature ductility was obtained in welds made both in the dry box and in air. Cleaning in chromic acid solution and welding in a highpurity dry-box welding atmosphere produced the most ductile welds. Recrystallizing the sheet prior to welding had no effect on weld ductility. Welds were made in air with ductility approaching the ductility of welds made in the dry box.

\section{Studies Made in the Dry Box}

Weldments were made in the dry box to determine the effect of cleaning procedure, prior sheet microstructure, and welding-atmosphere purity.

\section{Cleaning Procedures}

Four cleaning procedures were used to determine the best method of cleaning molybdenum before welding. These procedures were described earlier in the section on experimental procedures. Weld bend-test data from this study are shown in Table 4. At room temperature, the weld made in the sheet etched in the chromic acid solution exhibited the best ductility, the other methods producing welds of slightly lower ductility and about equal to each other. However, at $75 \mathrm{C}$, the weld made in the specimen etched electrolytically in Coon's electrolyte exhibited superior ductility to the other methods, the other three having equivalent ductility.

TABLE 4. EFFECTS OF CLEANING PROCEDURES ON THE DUCTILITY OF CARBONDEOXIDIED MOLYBDENUM WELDMENTS

\begin{tabular}{|c|c|c|c|}
\hline \multirow[b]{2}{*}{ Weld } & \multirow{2}{*}{$\begin{array}{l}\text { Cleaning } \\
\text { Procedure }\end{array}$} & \multicolumn{2}{|c|}{$\begin{array}{l}\text { Permanent Bend Angle(a) at Fracture, deg, in Tests at } \\
\text { Indicated Temperature }\end{array}$} \\
\hline & & $25 \mathrm{C}$ & $75 \mathrm{C}$ \\
\hline C20-1 & Emery paper & $\begin{array}{c}4,6,16,20,25,30, \\
30,40,50,50 \\
\underline{27}\end{array}$ & $\begin{array}{c}30,40,40,50,60,70, \\
70,80,90,90 \mathrm{NF}(\mathrm{b}) \\
\underline{62}\end{array}$ \\
\hline $\mathrm{CO}-2$ & Chromic acid & $\begin{array}{c}12,35,40,40,40 \\
40,40,50,60,60 \\
\underline{42}\end{array}$ & $\begin{array}{c}10,30,55,60,70,70 \\
80,90,90,90 \\
64\end{array}$ \\
\hline $\mathrm{CO}-3$ & $\begin{array}{l}\text { Coon's electro- } \\
\text { lytic etch }\end{array}$ & $\begin{array}{c}4,10,10,12,20,20 \\
30,30,40,40,50 \\
24\end{array}$ & $\begin{array}{c}50,50,60,60,80,80, \\
90,90,90 \mathrm{NF}, 90 \mathrm{NF}, 90 \mathrm{NF} \\
\underline{78}\end{array}$ \\
\hline $\mathrm{COO-4}$ & $\begin{array}{l}\mathrm{HCl}-\mathrm{H}_{2} \mathrm{O} \text { electro- } \\
\text { lytic etch }\end{array}$ & $\begin{array}{c}4,6,12,14,30,50, \\
50,50,70 \\
\underline{32}\end{array}$ & $\begin{array}{c}18,35,50,60,60,65 \\
70,90,90,90 \mathrm{NF} \\
\underline{63}\end{array}$ \\
\hline
\end{tabular}

(a) Average value for each set of samples is underlined.

(b) $\mathrm{NF}=$ no fracture. 
From the results of these studies it was concluded that no cleaning method was far superior to the others studied. The chromic acid solution (95 volume per cent $\mathrm{H}_{2} \mathrm{SO}_{4}, 4.5$ volume per cent $\mathrm{HNO}_{3}, 0.5$ volume per cent $\mathrm{HF}$, and $18.8 \mathrm{~g}$ per liter $\mathrm{Cr}_{2} \mathrm{O}_{3}$ ) was chosen for future work because it is easiest to use, and it would be the best method of those studied for cleaning complicated parts for welding. One major drawback to many electrolytic- and acid-cleaning methods is the severe grain-boundary attack. The chromic acid solution does not appear to attack molybdenum grain boundaries severely.

\section{Sheet Microstructure}

A study was made of the effect of recrystallizing molybdenum sheet before welding. It was thought that laminations present in fibered molybdenum sheet might give rise to porosity or a loss of weld ductility. In a previous study made on titanium-neutralized molybdenum alloys it was found that rolling at low temperatures produced serious laminations in the sheet which lowered weld ductility and increased scatter within the transition range. By recrystallizing fibered sheet it was thought that any effect of laminations would be eliminated.

Since the molybdenum sheet used for other studies was coarse grained, weld specimens were cut from a fibered sheet (C21). One specimen was welded in the as-rolled condition and the other was recrystallized at $2000 \mathrm{~F}$ for $2 \mathrm{hr}$ in flowing hydrogen before welding. Results of the bend tests are shown in Table 5. As can be seen from these data, there was no improvement in weldment bend ductility for the recrystallized molybdenum. As can be seen, however, the ductility of these welds, both on the fibered and on the recrystallized sheet, was slightly improved over that in Sheet C20.

TABLE 5. EFFECT OF SHEET MICROSTRUCTURE ON DUCTRITY OF CARBON-DEOXIDIZED MOLYBDENUM WELDMENTS

\begin{tabular}{|c|c|c|c|}
\hline \multirow[b]{2}{*}{ Weld } & \multirow{2}{*}{$\begin{array}{c}\text { Sheet Structure } \\
\text { Prior to } \\
\text { Welding }\end{array}$} & \multicolumn{2}{|c|}{$\begin{array}{c}\text { Permanent Bend Angle(a) at Fracture, deg, in Tests at } \\
\text { Indicated Temperature }\end{array}$} \\
\hline & & $25 \mathrm{C}$ & $75 \mathrm{C}$ \\
\hline C21-1 & Fibered & $\begin{array}{c}4,20,25,30,30 \\
40,50,90 \\
36\end{array}$ & $\begin{array}{c}40,50,60,90,90 \mathrm{NF}^{(\mathrm{b})} \\
90 \mathrm{NF}, 90 \mathrm{NF}, 90 \mathrm{NF} \\
\underline{75}\end{array}$ \\
\hline $\mathrm{C} 21-2$ & Recrystallized & $\begin{array}{c}4,14,18,35,35 \\
60,70,80 \\
40\end{array}$ & $\begin{array}{c}50,60,60,80,90 \mathrm{NF}, \\
90 \mathrm{NF}, 90 \mathrm{NF}, 90 \mathrm{NF} \\
\underline{76}\end{array}$ \\
\hline
\end{tabular}

(a) Average value for each set of samples is underlined.

(b) NF = no fracture. 
Welding-Atmosphere Purity

All molybdenum welding done previously had been done in a highpurity welding atmosphere. If welds could be made in a lower purity atmosphere, time and cost could be lowered. By purging the dry box to a vacuum of $100 \mu$ of mercury, the use of a diffusion pump would be eliminated and pumping time would be less. By testing a weld made in a low-purity atmosphere, the possible effects of a slightly contaminated atmosphere were checked. The methods for obtaining high- and low-purity atmospheres were discussed in an earlier section.

Table 6 lists the data for the welds made in high- and low-purity helium atmospheres. The welds made in high-purity helium had better room-temperature ductility, but ductility at $75 \mathrm{C}$ was comparable. It was concluded that welds with some ductility can be obtained in lower purity atmospheres, but higher purity welding atmospheres should be used to insure the best room-temperature ductility.

TABLE 6. EFFECT OF WELDING-A TMOSPHERE PURITY ON THE DUCTILITY OF CARBON-DEOXIDIZED MOLYBDENUM WELDS

\begin{tabular}{|c|c|c|c|}
\hline \multirow[b]{2}{*}{ Weld } & \multirow{2}{*}{$\begin{array}{l}\text { Ultimate } \\
\text { Vacuum, } \\
\mu \text { of mercury }\end{array}$} & \multicolumn{2}{|c|}{$\begin{array}{c}\text { Permanent Bend Angle(a) at Fracture, deg, in Tests at } \\
\text { Irdicated Temperature }\end{array}$} \\
\hline & & $25 \mathrm{C}$ & $75 \mathrm{C}$ \\
\hline $\mathrm{C} 20-2$ & 0.1 & $\begin{array}{c}12,35,40,40,40, \\
40,40,50,60,60 \\
\underline{42}\end{array}$ & $\begin{array}{c}10,30,55,60,70,70,80 \\
90,90,90 \\
64\end{array}$ \\
\hline C20-5 & 100.0 & $\begin{array}{c}4,8,25,30,30,30, \\
35,40,40,40 \\
28\end{array}$ & $\begin{array}{l}16,40,40,50,50,50,60 \\
80,90,90 \\
57\end{array}$ \\
\hline
\end{tabular}

(a) Average value for each set of samples is underlined.

\section{Studies Made in Air}

Since it would not always be practical to weld molybdenum in a dry box, a preliminary study was made to determine if ductile molybdenum welds could be made outside the dry box. The shielding methods tried and welding data were previously given in Table 3. Of the shielding devices studied, a ceramic cup and trailing shield unit produced welds with the best ductility. Insufficient data are available to determine the effectiveness of the leading and dragging shields although they appear promising. Bend-test data for the welds made in air are given in Table 7. 
TABLE 7. BEND- TEST DATA FOR WELDS MADE IN AIR

Welds Stress Relieved $1 \mathrm{Hr}$ at $1800 \mathrm{~F}$ in Hydrogen

\begin{tabular}{|c|c|c|c|c|c|c|}
\hline \multirow[b]{3}{*}{ Weld } & \multirow{3}{*}{$\begin{array}{l}\text { Type of } \\
\text { Shield }\end{array}$} & \multicolumn{3}{|c|}{ Gas Flow, cfh } & \multirow{2}{*}{\multicolumn{2}{|c|}{$\begin{array}{c}\text { Permanent Bend Angle(a) at Fracture, deg, in Tests } \\
\text { at Indicated Temperature }\end{array}$}} \\
\hline & & \multirow[b]{2}{*}{ Cup } & \multirow[b]{2}{*}{ Backup } & \multirow{2}{*}{$\begin{array}{l}\text { Trailing } \\
\text { Shield }\end{array}$} & & \\
\hline & & & & & $25 \mathrm{C}$ & $75 \mathrm{C}$ \\
\hline$C 20-A$ & 3/8-in. cup & 40 & 30 & -- & $\begin{array}{r}0.0,10,20 \\
\underline{7.5} \\
\end{array}$ & $\begin{array}{r}2.4,4,6.16 \\
\underline{6.4}\end{array}$ \\
\hline $\mathrm{C} 20-\mathrm{B}$ & 5/8-in. cup & 30 & 30 & -- & $\begin{array}{c}6,10,10,14,20 \\
20,20,30,30 \\
\underline{17}\end{array}$ & $\begin{array}{c}20,30,40,40,40 \\
45,45,65,65,85 \\
\underline{48}\end{array}$ \\
\hline $\mathrm{C} 20-\mathrm{C}$ & 5/8-in. cup & 40 & 30 & -- & $\begin{array}{l}10,16,30,30,35 \\
40,50,50,50,55 \\
\underline{37}\end{array}$ & $\begin{array}{c}35,45,45,55,70 \\
70,80,85,85,90 \\
\underline{66}\end{array}$ \\
\hline $\mathrm{C} 20-\mathrm{D}$ & 5/8-in. cup & 40 & 30 & -- & Not tested at $25 \mathrm{C}$ & $\begin{array}{l}2,6,18,30,40,40, \\
50,50,60,60,70,80 \\
80,90,90 \mathrm{NF}(\mathrm{b}), 90 \mathrm{NF} \\
\underline{54}\end{array}$ \\
\hline $\mathrm{C} 20-\mathrm{E}$ & 5/8-in. cup & 80 & 30 & -- & $\begin{array}{c}4,10,14,20,40 \\
40,40,50,60 \\
\underline{31}\end{array}$ & $\begin{array}{c}18,30,45,50,60 \\
70,70,70,90 \mathrm{NF} \\
\underline{57}\end{array}$ \\
\hline $\mathrm{C} 20-\mathrm{F}$ & 5/8-in. cup & 15 (argon) & 30 & -- & $\begin{array}{c}8,14,18,20,20, \\
25,30,30,35,65 \\
\underline{26}\end{array}$ & $\begin{array}{c}2,8,20,30,30,40 \\
50,60,60,90 \mathrm{NF} \\
\underline{39}\end{array}$ \\
\hline$C 20-G$ & $\begin{array}{c}\text { Trailing } \\
\text { shield }\end{array}$ & 40 & 30 & 30 & $\begin{array}{c}0,30,30,40,40 \\
50,55,60,70 \\
\underline{46}\end{array}$ & $\begin{array}{c}2,8,60,75,80,80 \\
80,85,85,90,90 \mathrm{NF} \\
\underline{67}\end{array}$ \\
\hline $\mathrm{C} 20-\mathrm{H}$ & Plastic bag & 40 & 30 & - & $\begin{array}{r}0.8,35 \\
\underline{14}\end{array}$ & $\begin{array}{c}16,50,60,80,90 \mathrm{NF} \\
\underline{59}\end{array}$ \\
\hline C20-I & Plastic bag & 40 & 15 & -- & $\begin{array}{c}0,0,6,30,40, \\
40,45 \\
\underline{23}\end{array}$ & $\begin{array}{c}40,50,50,60,65 \\
70,70,90 \mathrm{NF} \\
\underline{62}\end{array}$ \\
\hline $\mathrm{C} 20-\mathrm{J}$ & $1 / 2$-in. cup & 40 & 20 & $-\infty$ & $\begin{array}{c}0,16,20,20 \\
\underline{14}\end{array}$ & $\begin{array}{c}2,40,60,70 \\
\underline{43}\end{array}$ \\
\hline
\end{tabular}

(a) Average value for each set of samples is underlined.

(b) $\mathrm{NF}=$ No fracture, $90 \mathrm{deg}$ is limit of equipment. 
Inert-Gas-Shielding Cup

The inert-gas-shielding cup was tried initially to be used as a basis for comparison of the effectiveness of the other shielding devices. This type of shield is easier to use and allows the best visibility of the arc. Ductility of initial welds made using a ceramic inert-gas-shielding cup was surprisingly good at room temperature. An investigation was then set up to study the effects of: (1) cup size, (2) helium-flow rate, and (3) argon versus helium as a shielding gas. Cups with 3/8- and 5/8-in.-diameter gas orifices were used, helium flows of 30,40 , and $80 \mathrm{cfh}$ were tried, and one weld was made with a 15-cfh flow of argon. All welds were made with a helium-gas backup of $30 \mathrm{cfh}$. One other weld of this type (C20-J) will be discussed under a later section on welds made in the plastic bag.

Butt welds were made using 3/8- and 5/8-in.-diameter ceramic inert-gas-shielding cups and a 40-cfh helium flow to study the effect of nozzle size. The weld made using the 3/8-in. nozzle (C20-A) was badly cracked for about half of its length. Bend tests of the sound portions of this weld indicated a much lower ductility than the weld made using the 5/8-in. nozzle and the same helium flow (C20-C). Work done by other investigators has shown that lower helium flows must be used with the smaller diameter cup. (2) Probably at the 40-cfh helium flow the gas envelope was turbulent when using the 3/8-in. cup and a lower flow rate would produce a more ductile weld. The 5/8-in. nozzle, however, appeared to give better protection in the hot zone immediately ahead of the molten weld pool and prevented oxidation of this area before welding.

A study of the effect of gas flow was made with a 5/8-in. ceramic cup and helium flows of $30(\mathrm{C} 20-\mathrm{B}), 40(\mathrm{C} 20-\mathrm{C})$, and $80(\mathrm{C} 20-\mathrm{E}) \mathrm{cfh}$. The weld made with the 40-cfh helium flow had the best bend ductility. The weld made with the 80-cfh flow was only slightly less ductile and the weld made with $30 \mathrm{cfh}$ of helium was considerably less ductile at room temperature and slightly less ductile at $75 \mathrm{C}$. There is probably an optimum helium flow between 40 and $80 \mathrm{cfh}$. Below this optimum, not enough gas is provided to the weld area to give adequate protection from the air, while at higher flows the gas becomes turbulent and air is entrapped in the helium envelope.

Argon was used with the 5/8-in. nozzle to compare it with helium for shielding ability. Work done by previous investigators has shown the optimum argon flow for a 5/8-in. nozzle to be about $15 \mathrm{cfh}$ (2) The weld (C20-F) was made with a fixed electrode with a 3/16-in. nozzle-to-work distance and a 15-cfh flow of argon. The weld bead was narrow and had deep grooves at each fusion line. Bend tests showed this weld to be less ductile than welds made with $40 \mathrm{cfh}$ of helium.

All weld beads had oxidized surfaces when the ceramic cup was used. This appears to be only surface oxidation that occurs after the weld has solidified and has no effect on weld ductility. 


\section{Leading-Trailing Shield Unit}

It was originally thought that molybdenum-weldment ductility could be improved by use of a leading-trailing shield similar to those used to shield titanium to protect the completed weld. The leading-trailing shield unit (shown in Figure $3 \mathrm{~b}$ ) consisted of a inert-gas-shielding cup to shield the electrode and molten pool and a leading shield to protect the molybdenum ahead of the arc.

Welds made with this unit had only a slightly higher ductility than welds made with the ceramic cup. The weld bead had a bright surface when the trailing shield was used. However, as was shown with the ceramic cup, surface oxidation after the weld had solidified did not appear to affect weldment ductility. A trailing shield would be useful where multipass welds are made to facilitate cleaning between passes.

\section{$\underline{\text { Leading Shield }}$}

It was shown in work done with the shielding cup and the leadingtrailing shield that protection of the solidified weld was not necessary to produce welds with room-temperature ductility. However, it was believed that the leading portion of the leading-trailing shield unit might have improved the weldment ductility by preventing oxidation of the unwelded joint ahead of the molten weld pool. Oxidation of the unwelded portion of the joint would cause a loss in ductility in a material such as molybdenum, which is embrittled by minute quantities of oxygen.

The results of the bend tests on a weld made using the leading shield were inconclusive. The weld became badly oxidized during the stress relief and the ductility of a pilot weld made using the inert-gas-shielding cup was low, indicating the possible presence of contaminants in the shielding gas. Future work is planned using the leading shield.

\section{$\underline{\text { Plastic Bag Shield }}$}

The plastic bag was used to shroud the welding area much the same as the dry box. The bag was purged of air by flowing helium through it, and a positive pressure of helium was maintained for welding. It was thought that this would provide an improved atmosphere for welding of molybdenum.

Welds made with this method ( $\mathrm{C} 20-\mathrm{H}$ and $\mathrm{C} 20-\mathrm{I}$ ) had gross porosity at the fusion line. This porosity in welds made in the plastic bag may have been due to one of the following. First, the pressure in the bag was greater than the pressure during welding with a cup or trailing shield. Gases formed in the molten molybdenum may not have been able to escape as readily because of the increased pressure. Second, gas flow was not 
directed on the joint by a nozzle, and this may have caused any air in the bag to be drawn into the weld area. Air may have leaked into the bag through leaks, especially in the case of Weld $\mathrm{C} 20-\mathrm{H}$ when the bag had a hole burned into it at the start of the weld. Finally, the weld penetration was not so great in these welds, with the same current, voltage, and speed as in previous welds, when using the special jig designed for welding in the bag. If the jig chilled the weld faster than normal, the weld may have solidified before the gases formed during welding had an opportunity to escape. However, the mass of the copper jig used for the welds made in the bag was less than the mass of the jig used for other welds made in the dry box and in air and probably did not produce a more rapid chilling. Another weld (C20-J) was made using this jig and a 1/2-in.-diameter ceramic shielding cup without the bag. The groove formed by the hold-down plates was steeper than that used in the other jig and the electrode had to extend further from the cup. This weld was not protected as well as other welds made in air. This weld also had a large amount of porosity, which would indicate that the porosity of welds made in the plastic bag was not due to greater gas pressure in the bag.

\section{Dragging Shield}

In order to improve the welding technique for welding molybdenum outside the dry box, a shield was devised which might simulate welding in the dry box as nearly as possible. This shield consisted of a chamber which was dragged along in contact with the sheet being welded. Figure 3d shows the dragging shield in welding position. The shield was purged with helium and a flow of helium was maintained throughout the welding operation.

As with the leading shield, the bend-test results were inconclusive. It is believed that the shielding gas was contaminated. The weld also became badly oxidized during the stress-relief treatment, which may have embrittled it to some extent.

Weld Porosity

Radiographs of molybdenum weldments used in this study showed the following:

(1) Butt welds made in the dry box and in air had varying amounts of porosity near the fusion line.

(2) Bead-on-plate welds made in the dry box and in air contained no porosity.

Gross porosity was found in welds made in the plastic bag, as discussed thoroughly in a previous section. There are three possible reasons 
for the porosity found in butt joints made in air. First, after being exposed to air for a period of time, slight oxidation might occur along laminations in the sheet near the sheet edge. The cleaning method used might not be able to remove this oxide, and the oxide might vaporize or be reduced by residual carbon during welding. Second, the backup gases coming through the butt joint ahead of the arc might cause turbulence in the shielding gas, drawing air into the shield. This oxidation could be the cause for the porosity. Shield interruptions by backup gases would not occur in the case of bead on plate welds. Third, the porosity could be caused by contaminants in the shielding gas. Since the equipment is idle for periods of time, moisture is picked up and might be a source of contamination. However, since no porosity was found in bead on plate welds, the first two reasons appear more valid.

One butt weld was made in the dry box to determine if the porosity found in butt welds made in air was due to contaminated shielding gases, shield interruption, or to oxides or entrapped air in laminations near the sheet edge. This butt weld had a slight amount of porosity and was comparable to the least porous welds made in air. This would indicate that the greatest portion of the porosity found in butt welds made in air was due to contaminated shielding gas or shield interruption while a small portion was due to oxides or entrapped air on the sheet edges. Even though weldment ductility could not be related to the amount of porosity in the welds tested, steps should be taken to eliminate porosity, since it is an indication of the presence of oxygen in the weld.

\section{Tungsten Contamination}

While conducting welding studies in air, it was noted that the tip of the tungsten electrode was sometimes molten and small drops of tungsten were seen dropping into the molten molybdenum weld pool. Tungsten contamination may be the cause of some of the low bend angles found in tungsten-arc welds in molybdenum. This tungsten contamination was not noticed in welds made in the $d r y$ box, either because the arc is too distant from the view ports to notice it or the electrode was cooled more effectively, since it did not protrude from the collet as far as was required when a cup or other type of shield was used outside the dry box. A series of tests was made in an attempt to determine the extent of tungsten contamination.

The sheet and the electrode were weighed to the nearest $0.1 \mathrm{mg} \mathrm{im}-$ mediately before welding and again after welding to determine weight losses or gains. Both the sheet and the electrode were found to lose weight during welding, making it impossible, by this method, to determine the actual extent of tungsten contamination. Molybdenum weight losses occurred in air, probably as a combination of oxidation and vaporization. However, in the best dry-box atmosphere, molybdenum weight loss was primarily due to vaporization. 
One electrode was weighed, used for four welds in the dry box, and reweighed. The total tungsten weight loss was $0.9 \mathrm{mg}$, which was calculated to be $0.06 \mathrm{mg}$ per in. of weld. Assuming complete pickup in the weld metal, the contamination amounted to $0.003 \mathrm{w} / \mathrm{o}$ tungsten.

Urbain (3) used a radioactive tracer of tungsten (tungsten-187) with a half life of $24.1 \mathrm{hr}$ to determine the extent and location of tungsten losses. He found that most of the tungsten loss was in the weld metal, with the remaining losses either appearing as condensed vapor on the base metal or lost as fumes of tungsten oxide. Total weight losses found by Urbain on welds in stainless steel made with straight-polarity direct current were about double those calculated in the Battelle study using thoriated tungsten electrodes.

Another source of tungsten contamination may occur when the arc is struck. In order for the automatic head to strike an arc, the electrode contacts the plate and is then pulled back a preset distance. When the electrode makes contact, the molybdenum may become contaminated with tungsten near the start of the weld. One weld, whose bend specimens were tested in order from the start of the weld, had its lowest bend angles near the weld start. These low bend angles may have been due to tungsten contamination.

To determine the effect of tungsten contamination, a weld was made with a tungsten addition to the last one-half of the weld. The tungsten was added as a piece of zirtung electrode laid in a butt joint. The amount of tungsten in the weld was calculated to be about $3.2 \mathrm{w} / 0$. This was considerably more tungsten than would be expected under normal welding conditions. The bend-test data for this weld (Table 8) indicate that the weldment ductility was lowered by the addition of tungsten. As can also be seen from the data the bend ductility was also lower than expected for a weld made in a high-purity dry-box atmosphere without a tungsten addition. This may have been due to the fact that this weld became badly oxidized during the stress-relieving treatment, possibly contaminating the weld to some extent. The addition of $3.2 \mathrm{w} / \mathrm{o}$ tungsten to the weld did not appear to have lowered the ductility of the weld to as great a degree as had been anticipated. If this large an addition of tungsten did not greatly affect the weldment ductility, then the small quantities picked up during welding may not have serious effects.

TABLE 8. THE EFFECT OF TUNGSTEN ON THE BEND DUCTIITY OF MOLYBDENUM WELDMENTS AT $25 \mathrm{C}$

\begin{tabular}{ccc}
\hline $\begin{array}{c}\text { Tungsten } \\
\text { Weld }\end{array}$ & $\begin{array}{c}\text { Permanent Bend Angle }(\mathrm{a}) \text { at Fracture, deg, in } \\
\text { Addests at } 25 \mathrm{C}\end{array}$ \\
\hline C20-7a & None & $6,6,14,20,30,30,30,30,80,27.3$ \\
C20-7b & 3.2 & $0,0,10,12,12,14,20,30,35,14.6$ \\
\hline
\end{tabular}

(a) Average value of each set of samples is underlined. 


\section{CONSISTENCY RUN}

A consistency run was made to determine if inert-gas-shielded tungsten-arc welds could be produced with the same ductility in sheet from different heats of arc-cast carbon-deoxidized molybdenum. Six heats of molybdenum of about the same carbon content were used for this study. Half of the specimens were welded in the dry box and the other half were welded in air, using the best welding conditions found.

\section{Material}

Molybdenum from six different heats containing about $0.020 \mathrm{w} / \mathrm{o}$ carbon was used for this study. Fabrication by normal commercial practice was specified. However, the sheet was fabricated in slightly different manners, as shown in Table 9. Bend specimens from each of the sheets were tested after they had been stress relieved at $1800 \mathrm{~F}$ for $\mathrm{l} \mathrm{hr}$ in hydrogen. The bend-test data are given in Table 10.

Sheets C24 and C26 showed low room-temperature ductility. Metallographic examination of the sheets showed a coarse-grained structure for Sheets C24 and C26. The remaining sheets were more fibered, C21 showing the most fibering. All sheets except $\mathrm{C} 24$ and $\mathrm{C} 26$ were cross rolled from the sheet bar.

As will be discussed in a later section, welds in Sheets C21, C22, and C23 were usually more ductile than welds in Sheets C24, C25, and C26. The only major difference which was found in the available fabrication data was the method of fabricating the sheet bar. A similar ranking of the sheet ductility might also have been evident if the bend tests could have been carried out to fracture for all specimens.

\section{Procedures}

Welding procedures used for the consistency run were those developed in the earlier work of this study. The sheet specimens were split into two groups, one to be welded in the dry box, the other to be welded in air. All welds were stress relieved at $1800 \mathrm{~F}$ for $1 \mathrm{hr}$ in flowing tank hydrogen. Testing procedures were the same as described earlier in the report. Procedures are listed in Table 11 . The results of this study were difficult to interpret, so a statistical analysis was made from the bend-test data. 
TABLE 9. FABRICATION DATA FOR 1/16-IN. CARBON-DEOXDIZED MOLYBDENUM SHEET USED IN THE CONSISTENCY RUN

\begin{tabular}{|c|c|c|c|c|}
\hline Sheet & $\begin{array}{l}\text { Carbon } \\
\text { Content, } \\
\text { w/o }\end{array}$ & Initial Breakdown & Intermediate Working & Finish Rolling \\
\hline $\mathrm{C} 21$ & 0.020 & $\begin{array}{l}\text { Extruded from } 6-1 / 2 \mathrm{in.} \text { in diameter } \\
\text { to } 4-1 / 4 \mathrm{in.} \text { in diameter at } 2300 \mathrm{~F} \text {, } \\
\text { annealed } 1 \mathrm{hr} \text { at } 2600 \mathrm{~F}\end{array}$ & $\begin{array}{l}\text { Rolled from } 3-21 / 32-\text { in. round } \\
\text { to } 1 \text { by } 4-\text { in. bar at } 2300 \mathrm{~F} \text {, } \\
\text { annealed } 1 \mathrm{hr} \text { at } 2300 \mathrm{~F}\end{array}$ & $\begin{array}{l}\text { Rolled(a) to } 0.060 \text { in. thick } \\
\text { at } 1800 \text { to } 2200 \mathrm{~F}\end{array}$ \\
\hline $\mathrm{C} 22$ & 0.015 & $\begin{array}{l}\text { Extruded from } 7-1 / 16 \text { in. in diameter } \\
\text { to } 4-1 / 4 \mathrm{in} . \text { in diameter at } 2300 \mathrm{~F} \text {, } \\
\text { annealed } 1 \mathrm{hr} \text { at } 2600 \mathrm{~F}\end{array}$ & $\begin{array}{l}\text { Rolled from } 3-21 / 32-\mathrm{in} \text {, round } \\
\text { to } 1 \text { by } 4-\mathrm{in} \text {. bar at } 2300 \mathrm{~F} \text {. } \\
\text { annealed } 1 \mathrm{hr} \text { at } 2600 \mathrm{~F}\end{array}$ & $\begin{array}{l}\text { Rolled(a) to } 0.060 \mathrm{in} \text {. thick } \\
\text { at } 1800 \text { to } 2200 \mathrm{~F}\end{array}$ \\
\hline $\mathrm{C} 23$ & 0.017 & $\begin{array}{l}\text { Extruded from } 6-5 / 8 \mathrm{in.} \text { in diameter } \\
\text { to } 4-1 / 4 \mathrm{in} \text {. in diameter at } 2300 \mathrm{~F} \text {, } \\
\text { annealed } 1 \mathrm{hr} \text { at } 2900 \mathrm{~F}\end{array}$ & $\begin{array}{l}\text { Rolled from } 3-29 / 32-i n \text {, round } \\
\text { to } 1 \text { by } 4-\mathrm{in} \text {, bar at } 2300 \mathrm{~F} \text {, } \\
\text { annealed } 1 \mathrm{hr} \text { at } 2300 \mathrm{~F}\end{array}$ & $\begin{array}{l}\text { Rolled }^{(a)} \text { to } 0.060 \mathrm{in} \text {, thick } \\
\text { at } 1800 \text { to } 2200 \mathrm{~F}\end{array}$ \\
\hline $\mathrm{C} 24$ & 0.020 & $\begin{array}{l}\text { Extruded from } 6-5 / 8 \mathrm{in.} \text { in diameter } \\
\text { to } 4-1 / 4 \mathrm{in} \text {. in diameter at } 2300 \mathrm{~F} \text {, } \\
\text { annealed } 1 \mathrm{hr} \text { at } 2600 \mathrm{~F}\end{array}$ & $\begin{array}{l}\text { Forged from } 3-1 / 2-i n \text {. round } \\
\text { to } 1 \text { by } 4-\mathrm{in} \text {. bar at } 2400 \mathrm{~F} \text {, } \\
\text { annealed } 1 \mathrm{hr} \text { at } 2500 \mathrm{~F}\end{array}$ & $\begin{array}{l}\text { Rolled(b) to } 0.060 \text { in. thick } \\
\text { at } 1800 \text { to } 2200 \mathrm{~F}\end{array}$ \\
\hline $\mathrm{C} 25$ & 0.017 & $\begin{array}{l}\text { Extruded from } 6-5 / 8 \mathrm{in.} \text { in diameter } \\
\text { to } 4-1 / 4 \mathrm{in}, \text { in diameter at } 2300 \mathrm{~F} \text {, } \\
\text { annealed } 1 \mathrm{hr} \text { at } 2600 \mathrm{~F}\end{array}$ & $\begin{array}{l}\text { Forged from } 3-15 / 16-\mathrm{in} \text {. round } \\
\text { to } 1 \text { by } 4-\mathrm{in} \text {, bar at } 2300 \mathrm{~F} \text {, } \\
\text { annealed } 1 \mathrm{hr} \text { at } 2600 \mathrm{~F}\end{array}$ & $\begin{array}{l}\text { Rolled }{ }^{(a)} \text { to } 0.060 \text { in. thick } \\
\text { at } 1800 \text { to } 2200 \mathrm{~F}\end{array}$ \\
\hline $\mathrm{C} 26$ & 0.021 & $\begin{array}{l}\text { Extruded from } 6-5 / 8 \mathrm{in.} \text { in diameter } \\
\text { to } 4-1 / 4 \mathrm{in} \text { in diameter at } 2300 \mathrm{~F} \text {, } \\
\text { annealed } 1 \mathrm{hr} \text { at } 2800 \mathrm{~F}\end{array}$ & $\begin{array}{l}\text { Forged from } 3-13 / 16-\mathrm{in} \text {, round } \\
\text { to } 1 \text { by } 4-\mathrm{in} \text {, bar at } 2300 \mathrm{~F} \text {, } \\
\text { annealed } 1 \mathrm{hr} \text { at } 2600 \mathrm{~F}\end{array}$ & $\begin{array}{l}\text { Rolled(b) to } 0.060 \mathrm{in} \text {. thick } \\
\text { at } 1800 \text { to } 2200 \mathrm{~F}\end{array}$ \\
\hline
\end{tabular}

(a) Sheet was cross rolled.

(b) Sheet was not cross rolled. 
TABLE 10. BEND-TEST DATA AT 25 C FOR SHEET USED IN THE CONSISTENCY RUN Stress Relieved $1 \mathrm{Hr}$ at $1800 \mathrm{~F}$ in Hydrogen

\begin{tabular}{lll}
\hline & $\begin{array}{c}\text { Carbon } \\
\text { Content, } \\
\text { w/o }\end{array}$ & Permanent Bend Angle (a), deg, in Tests at 25 C \\
Sheet & 0.020 & $90 \mathrm{NF}(\mathrm{b}), 90 \mathrm{NF}, 90 \mathrm{NF}, 90 \mathrm{NF}, 90 \mathrm{NF}, 90$ \\
$\mathrm{C} 21$ & $90 \mathrm{NF}, 90 \mathrm{NF}, 90 \mathrm{NF}, 90 \mathrm{NF}, 90 \mathrm{NF}, 90$ \\
$\mathrm{C22}$ & 0.015 & $90 \mathrm{NF}, 90 \mathrm{NF}, 90 \mathrm{NF}, 90 \mathrm{NF}, 90 \mathrm{NF}, 90$ \\
$\mathrm{C23}$ & 0.017 & $6,20,90 \mathrm{NF}, 90 \mathrm{NF}, 90 \mathrm{NF}, 59$ \\
$\mathrm{C25}$ & 0.020 & $90 \mathrm{NF}, 90 \mathrm{NF}, 90 \mathrm{NF}, 90 \mathrm{NF}, 90 \mathrm{NF}, 90$ \\
$\mathrm{C26}$ & 0.017 & $60,60,90 \mathrm{NF}, 90 \mathrm{NF}, 90 \mathrm{NF}, 78$ \\
\hline \hline
\end{tabular}

(a) Average value for each set of samples is underlined. (b) $\mathrm{NF}=$ no fracture.

TABLE 11. PROCEDURE FOR CONSISTENCY RUN OF WELDS MADE IN THE DRY BOX AND IN AIR

\begin{tabular}{|c|c|c|}
\hline & $\begin{array}{l}\text { Welds Made in the } \\
\text { Dry Box }\end{array}$ & Welds Made in Air \\
\hline Cleaning Procedure & Chromic acid etch & Chromic acid etch \\
\hline Sheet Condition & As rolled & As rolled \\
\hline Shielding Device & Dry box & 5/8-in. ceramic cup \\
\hline Ultimate Vacuum & $\begin{array}{l}0.1 \mu \text { of mercury, } \\
\text { atmosphere gettered }\end{array}$ & $\ldots$ \\
\hline Atmosphere & Grade A helium & Flowing Grade A helium \\
\hline Gas Flows & -- & Cup, $40 \mathrm{cfh}$; backup, $30 \mathrm{cfh}$ \\
\hline Current & $210 \mathrm{amp}$ & 212 to $240 \mathrm{amp}$ \\
\hline Arc Voltage & $20 \mathrm{v}$ & 16 to $16.5 \mathrm{v}$ \\
\hline Weld Speed & $12 \mathrm{ipm}$ & 12 ipm \\
\hline
\end{tabular}


$\underline{\text { Results }}$

From the data obtained by bend testing, it was difficult to determine if the differences among heats were significant. A statistical analysis was made of the data to determine significant differences. The analysis first showed that the standard error was $21.5 \mathrm{deg}$ of bending for all specimens tested. When the welds made in the dry box and the welds made in air were considered separately, temperature had a significant effect on weld ductility, much more so for the welds made in air. A significant difference in weldment ductility also was found for the six heats of arc-cast molybdenum. This difference was greater for welds made in air, probably due to contamination during welding. The analysis also showed a possible significant difference between welds made in air and those made in the dry box, the welds made in the dry box being more ductile and consistent.

The greater difference for different heats of molybdenum welded in air may have been due to the welding procedure. Welds made one day were more ductile than welds made the following day. The welding equipment may have picked up moisture, even though helium was allowed to flow through the equipment for several minutes and welds were made on scrap to dry out the equipment before welding. Another possibility is that the surface of the molybdenum sheet may have become slightly oxidized overnight, even though kept in a desiccator until being welded.

An examination of the average bend-angle data given in Table 12 was made to determine between which heats or groups of heats significant differences in weldment ductility existed. Table 13 indicates which groups of heats possessed no significant difference and also indicates between which groups of heats a significant difference lies. This table is based on significant differences calculated for a 5 per cent probability level of risk.

An examination of the bend-test data for the consistency run indicated that welds in Sheets C21, C22, and C23 were more ductile than welds in Sheets C24, C25, and C26. From the fabrication data for these sheets (Table 9) the only difference found which might explain this is that the sheet bar was rolled in the case of Sheets C21, C22, and C23, while it was forged in the case of Sheets C24, C25, and C26. However, the fabrication data on the six commercial heats used in this study are not so complete as would be desired. 
TABLE 12. AVERAGE BEND ANGLE AND FACTORS FOR DETERMINING SIGNIFICANT DIFFERENCES FOR HEATS TESTED IN CONSISTENCY RUN

\begin{tabular}{|c|c|c|c|c|c|c|c|}
\hline \multirow[b]{3}{*}{ Atmosphere } & \multirow[b]{3}{*}{ Rank } & \multicolumn{2}{|c|}{$25 C^{(a)}$} & \multicolumn{2}{|c|}{$75 c^{(a)}$} & \multicolumn{2}{|c|}{ Average(b) } \\
\hline & & & Average Bend & & Average Bend & & Average Bend \\
\hline & & Sheet & Angle, deg & Sheet & Angle, deg & Sheet & Angle, deg \\
\hline \multirow[t]{6}{*}{ Dry box } & 1 & $\mathrm{C} 23$ & 64.0 & $\mathrm{C} 22$ & 74.5 & $\mathrm{C} 23$ & 69.0 \\
\hline & 2 & $\mathrm{C} 22$ & 60.8 & $\mathrm{C} 23$ & 74.0 & $\mathrm{C} 22$ & 67.6 \\
\hline & 3 & $\mathrm{C} 21$ & 44.7 & $\mathrm{C} 25$ & 68.1 & $\mathrm{C} 21$ & 55.8 \\
\hline & 4 & $\mathrm{C} 24$ & 44.5 & $\mathrm{C} 21$ & 66.9 & $\mathrm{C} 24$ & 55.3 \\
\hline & 5 & $\mathrm{C} 25$ & 38.0 & $\mathrm{C} 24$ & 66.2 & $\mathrm{C} 25$ & 53.0 \\
\hline & 6 & $\mathrm{C} 26$ & 37.6 & $\mathrm{C} 26$ & 57.4 & $\mathrm{C} 26$ & 47.5 \\
\hline \multirow{6}{*}{$\begin{array}{l}\text { Air, helium } \\
\text { shield }\end{array}$} & 1 & $\mathrm{C} 21$ & 36.4 & C21 & 67.9 & $\mathrm{C} 21$ & 52.1 \\
\hline & 2 & $\mathrm{C} 23$ & 28.5 & $\mathrm{C} 23$ & 58.7 & $\mathrm{C} 23$ & 43.6 \\
\hline & 3 & $\mathrm{C} 22$ & 21.7 & $\mathrm{C} 22$ & 57.7 & $\mathrm{C} 22$ & 39.7 \\
\hline & 4 & $\mathrm{C} 26$ & 17.8 & $\mathrm{C} 25$ & 51.2 & $\mathrm{C} 25$ & 34.1 \\
\hline & 5 & $\mathrm{C} 25$ & 17.0 & $\mathrm{C} 26$ & 40.8 & $\mathrm{C} 26$ & 29.3 \\
\hline & 6 & $\mathrm{C} 24$ & 8.2 & C24 & 31.0 & C24 & 19.6 \\
\hline
\end{tabular}

(a) Significant difference (probability level of risk, 5 per cent), 13.3 deg. Highly significant difference (probability level of risk, 1 per cent), 17.6 deg.

(b) Significant difference (probability level of risk, 5 per cent), 9.4 deg. Highly significant difference (probability level of risk, 1 per cent), $12.4 \mathrm{deg}$. 
TABLE 13. SIGNIFICANT DIFFERENCES AMONG GROUPS OF SHEETS

5 Per Cent Probability Level of Risk

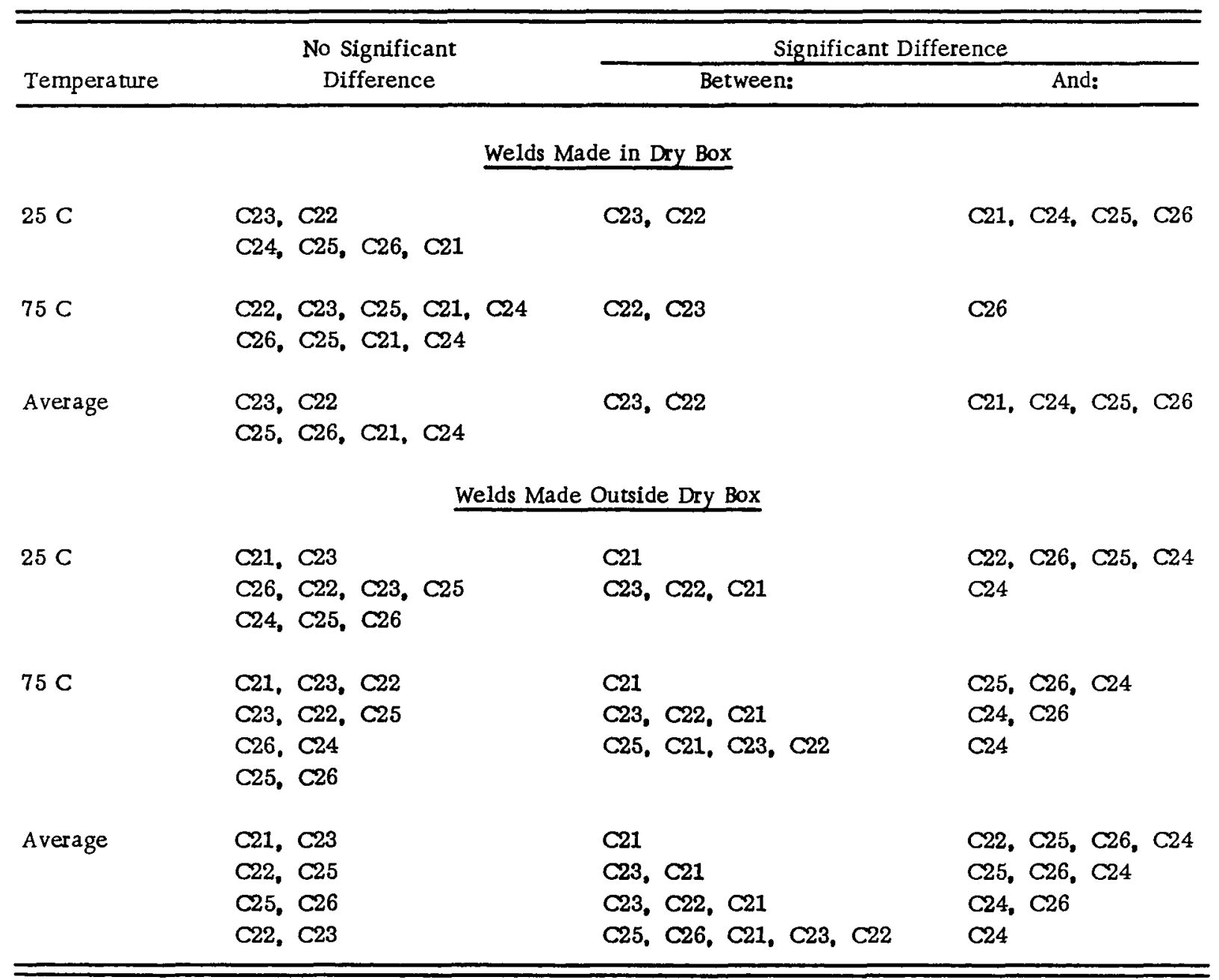




\section{SUMMARY}

Weldments were made in the dry box to determine the effects of sheet cleaning procedures, recrystallization of sheet prior to welding, and atmosphere purity on the ductility of molybdenum weldments. Preliminary studies were also made of supplementary shielding methods for welding molybdenum outside the dry box. The information gained from these two studies was then used for a consistency run to determine if weldments with consistent ductility could be made in different heats of arc-cast carbondeoxidized molybdenum. Bend tests were made at room temperature and at $75 \mathrm{C}$. All welds showed some ductility at room temperature. The experimental work showed that the welds made in the dry box showed better and more consistent ductility than welds made in air.

The studies made in the dry box showed that none of the cleaning procedures studied was outstanding insofar as final weldment ductility was concerned. A chromic acid solution (95 volume per cent $\mathrm{H}_{2} \mathrm{SO}_{4}, 4.5$ volume per cent $\mathrm{HNO}_{3}, 0.5$ volume per cent $\mathrm{HF}$, and $18.8 \mathrm{~g}$ per liter $\mathrm{Cr}_{2} \mathrm{O}_{3}$ ) was more desirable because of its ease of use. It would also be the best method for cleaning complex shapes for welding. Recrystallization of the fibered sheet before welding had no effect on weldment ductility. The weld made in the lower purity atmosphere was slightly less ductile than welds made using a high-purity dry-box atmosphere.

Of the three shielding methods studied in air, the two best methods produced weldments of about the same ductility. These methods were the inert-gas-shielding cup, and the leading-trailing shield unit. A more extensive study was made of the cup shield. It was found that a 5/8-in. gas nozzle was a more effective shield for welding molybdenum than a 3/8-in. nozzle, that helium was more effective and produced a better weld contour than argon, and that the optimum helium flow using the 5/8-in. cup was about $40 \mathrm{cfh}$.

The leading-trailing shield unit protected the unwelded joint ahead of the arc, the molten weld pool, and the solidified weld. Outside of protecting the molten weld pool, the most important function of this unit was the protection of the unwelded joint ahead of the molten pool from oxidation. Surface oxidation after the weld solidified did not appear to affect ductility. The other shield studied was a plastic bag, purged of air by flowing helium. This shield was to shroud the weld from air much the same as a dry box. This shield was abandoned because it was cumbersome, and did not allow a clear view of the weld being made. The welds made in the plastic bag contained gross porosity and were no more ductile than those obtained with the inert-gas-shielding cup or the leading-trailing shield unit.

The results of the consistency $r$ un on welds made in the dry box showed a significant difference in ductility for welds made in different heats 
of arc-cast carbon-deoxidized molybdenum of about the same carbon content. A greater difference was found among heats for welds made in air, probably because of contamination of some of the welds during welding. The ductility of welds made in air was lower and much less consistent than welds made in the dry box. This shows that further work is required to improve shielding and welding methods outside the dry box,

The investigation of the ductility of molybdenum weldments made in air showed a wide variation in results. This wide variation might be due to several causes which should be eliminated, if possible, by a test program. The most likely source of trouble appears to be water vapor which could be picked up in varying amounts from the welding equipment. Present attempts to dry out equipment before use may require improvement or the welding should be carried out in a controlled-humidity room.

Future work is planned to improve shielding methods, study the effect of welding variables (current, arc voltage, and weld speed), and study the inert-gas-shielded consumable-electrode welding of molybdenum sheet in thicknesses from $1 / 32$ to $1 / 2$ in.

\section{REFERENCES}

(1) Weare, N. E., Monroe, R. E., and Rengstorff, G. W., "Fabrication and Welding of Arc-Cast Molybdenum", BMI-1037 (September 6, 1955).

(2) Gibsen, G. J., "Gas Flow Requirements for Inert-Gas-Shielded Arc Welding", Welding Journal, 32 (4), Research Supplement, $198 \mathrm{~s}-208 \mathrm{~s}$ (1953).

(3) Urbain, G., "Measuring the Tungsten Contamination in Inert-Gas-Arc Welding", Welding Journal, 30 (5), Research Supplement, 260 s - 264 s (1951).

NEW / REM / DCM:pa 